\title{
PRODUCTION AND CHARACTERIZATION OF PHA FROM RECOMBINANT E. COLI HARBOURING PHACI GENE OF INDIGENOUS PSEUDOMONAS SP. LDC-5 USING MOLASSES
}

\author{
Saranya V., Shenbagarathai R.*
}

PG and Research Department of Zoology and Biotechnology, Lady Doak College, Madurai, India.

Submitted: December 31, 2009; Returned to authors for corrections: December 09, 2010; Approved: May $16,2011$.

\begin{abstract}
Polyhydroxyalkanoates (PHA) are biodegradable and biocompatible green thermoplastics, synthesized by wide variety of bacteria as an intracellular carbon and energy storage intermediate. They are used as an alternative to nonrenewable petroleum derived plastics. The current interest in these biopolyesters is stimulated by the search for cost-effective capitalized production. This paper attempts to achieve maximized production rate from recombinant system using inexpensive substrate. Molasses from agro-industrial waste was used to produce PHA from recombinant E.coli in batch culture. PHA yield in molasses $(3.06 \mathrm{~g} / \mathrm{L} \pm 0.05$ $75.5 \%)$ was higher than that of sucrose $(2.5 \mathrm{~g} / \mathrm{L} \pm 0.05-65.1 \%)$. Properties of the polymer produced from molasses and sucrose were analyzed by DSC, TGA, DTA, GC/MS, TLC and optical rotation studies. The findings suggested that molasses enhanced PHA production in recombinant E.coli.
\end{abstract}

Key words: Polyhydroxyalkanoates, molasses, cost effective production.

\section{INTRODUCTION}

Polyhydroxyalkanoates (PHAs) are optically active polyesters of natural origin (15). It is synthesized in microorganisms as intracellular carbon reserve material during the excess of carbon under nitrogen limiting conditions. It can be utilized by micro-organism as a reserved material at the time of its need (13). As it has material properties (Molecular weight, Melting temperature, Glass transition temperature) similar to synthetic polymers (24), it is trusted to triumph over the problems and harmful effects of plastic wastes $(3,16,22)$. Owing to these features, PHAs have drawn much attention for numerous industrial applications.

A major limitation to achieve marketable production of
PHAs is their higher price than synthetic fossil fuel based plastics. The high production cost is the most important barrier hindering PHA to compete the market with conventional synthetic polymers. For instance, Zeneca Bio Products (Billingham, UK) produced approximately 1,000 tons per year of $\mathrm{PHB} / \mathrm{V}$ copolymer at ca. US $\$ 16 / \mathrm{kg}$. The price of conventional petrochemical plastics is less than US $\$ 1 / \mathrm{kg}(11$, 23). To achieve successful commercialization of PHA, economic production system must be sort out. As the cost of raw material (substrate, bacterial strain) is one of the major factors influencing the economy of production $(18,20)$, the present study is concentrated on the cost effective production of PHA by combining the use of inexpensive substrate (molasses) for the growth of the potential strain.

*Corresponding Author. Mailing address: PG and Research Department of Zoology and Biotechnology, Lady Doak College, Madurai, India.; E-mail: shenbagarathai@rediffmail.com 
Information on Physio - chemical material property is obligatory for the possible usage of polymer. For example, PHA that is semi-crystalline, with low melting point $\left(\mathrm{T}_{\mathrm{m}}\right)$, high elongation to break can be used for biomedical applications. Based on these above said concerns, the present study is focused on to achieve lower production cost using molasses as substrate for recombinant strain and characterization of material properties of PHA to ensure quality product for medical application.

\section{MATERIALS AND METHODS}

\section{Bacterial strain and Growth conditions}

Recombinant E.coli harboring phaCl of Pseudomonas.sp.LDC-5 $(18,19)$ was used in this study. The purity of the strain was ascertained by repeated streaking on LB medium. It was grown in PHA accumulating RC medium $(8,18)$ supplemented with $1 \%$ carbon source when needed.

\section{Carbon Substrate}

PHA production was studied using the molasses (dark brown in colour) obtained from sugar refinery mill, Madurai District (India). For comparative assessment expensive carbon substrate, sucrose (Himedia) was used.

\section{Fermentor Studies}

PHA production was achieved by using lab scale fermentor. Seed cultures were inoculated into sterilized minimal media (RC) supplemented with inexpensive / expensive substrates. Fermentation was carried out using $3.5 \mathrm{~L}$ Bio console ADI (025) Fermentor (Applikon Biotechnology (Holland). Parameters used for operation: $\mathrm{pH}$ (7.0), dissolved oxygen content (30\%), agitation speed (3000g) and temperature $\left(37^{\circ} \mathrm{C}\right)$. The $\mathrm{pH}$ was maintained robotically by the addition of $0.5 \mathrm{M} \mathrm{NaOH}$ and $0.5 \mathrm{M} \mathrm{HCl}$. Coconut oil mixed with water (1:1) was used as the anti foaming agent.

\section{Polymer Recovery}

Cultured broth was centrifuged at $8000 \mathrm{~g}$ for $10 \mathrm{~min}$ and the pellet was washed thoroughly with distilled water $(19,7)$.
PHA was extracted from the cells as per the method of Sujatha et al (2006). The recovered PHA was subjected to further analysis.

\section{Thin Layer Chromatography Analysis of \\ Polyhydroxyalkanoates}

$50 \mu \mathrm{L}$ sample of $48 \mathrm{~h}$ grown cells was spotted on to TLC plate prepared using silica gel and allowed to run in the solvent system consisting of ethyl acetate and benzene (1:1) for 40 min. For identification of PHA, TLC plate was kept inverted in a beaker containing iodine solution (Himedia) in a water bath $\left(100^{\circ} \mathrm{C}\right)$ for $5-10 \mathrm{~min}$ for saturation of iodine vapors. The yellowish green spots indicate the presence of PHA (9).

\section{Thermal analysis of polymeric samples}

Polymeric samples of approximately $2 \mathrm{mg}$ were encapsulated in an aluminum pan and placed in a Differential Scanning Colorimeter (DSC) chamber for analysis (TA INSTRUMENTS SDT Q600 V 8.3BUILD 101) (CECRI, Karaikudi). The samples were heated up to $1000^{\circ} \mathrm{C}$ at a rate of $20^{\circ} \mathrm{C}$ per minute under Nitrogen atmosphere. Data were analyzed by THERMAL ADVANTAGE Software. The melting temperature (Tm) was determined from the peaks of DSC endotherms (14). Thermal characterization by Thermo Gravimetric Analysis (TGA) and Differential Thermal Analysis (DTA) of recovered polymer was conducted with TA INSTRUMENTS SDT Q $600 \mathrm{~V} 8.3$ BUILD 101 at $1000^{\circ} \mathrm{C}$ at a rate of $20^{\circ} \mathrm{C}$ per minute under Nitrogen atmosphere. Alumina was used as reference sample.

\section{Derivatization of polymeric samples}

$5 \mathrm{mg}$ of polymer sample was mixed with $2 \mathrm{~mL}$ of $3.0 \%$ (v/v) sulfuric acid in methanol and $2 \mathrm{~mL}$ of chloroform, and the mixture was refluxed for $3.5 \mathrm{~h}$ at $100^{\circ} \mathrm{C}$ to convert monomer units to their corresponding ethyl ester (1). The mixture was cooled and washed with $10 \mathrm{~mL}$ of distilled water. The organic phase was collected and dried over $\mathrm{MgSO}_{4}$ and used for further analysis. 


\section{GC-MS analysis}

For molecular analysis of the methyl esters, a coupled GCMS was performed using a GC Clarus 500 Perkin Elmer, with Elite- $1(100 \%$ Dimethyl poly siloxane) capillary column (30 $\mathrm{mm} \times$ $0.25 \mathrm{~mm} \times 1 \mu \mathrm{m}$; carrier gas - He, $1 \mathrm{~mL} / \mathrm{min}$; temperature program $-110^{\circ} \mathrm{C}$ for $2 \mathrm{~min}$ then increased at $5^{\circ} \mathrm{C} / \mathrm{min}$ to $280^{\circ} \mathrm{C}$ and maintained) equipped with a Turbo mass gold model mass selective detector (PPRC, Tanjore). The mass spectra obtained were compared with the NIST '98 Mass Spectral Library with Windows Search Program version 2.1, National Institute of Standards and Technology (US Department of Commerce) with electron energy of $70 \mathrm{eV}$ and mass scan $(\mathrm{m} / \mathrm{z}) 45-50$.

\section{RESULTS AND DISCUSSION}

\section{Biosynthesis of polymer}

The influence of substrate (molasses and sucrose) on the growth and PHA production by recombinant E.coli harboring phaCl of Pseudomonas.sp.LDC-5 was investigated. The presence of bright spherical PHA granules in the cells were clearly demonstrated by phase contrast light microscope (OLYMPUSDP12-CX41) (Figure 1). The PHA yield was increased when molasses $(3.06 \mathrm{~g} / \mathrm{L} \pm 0.05-75.5 \%)$ was used as carbon source than with sucrose $(2.5 \mathrm{~g} / \mathrm{L} \pm 0.05-65.1 \%)$. Figure 2 illustrates the kinetics of the production.

The enhanced PHA production in molasses could be attributed by the composition of the substrate. The $\mathrm{C}: \mathrm{N}$ ratio has led to unbalanced nutrient condition, which in turn had led to inhibition of TCA cycle enzymes such as citrate synthase and isocitrate dehydrogenase and consequently have slowed down the TCA cycle. As a result, the acetyl co-A routed to PHA biosynthesis (2). Figure 3 depicts that the production cost using molasses is relatively lower compared to sucrose.
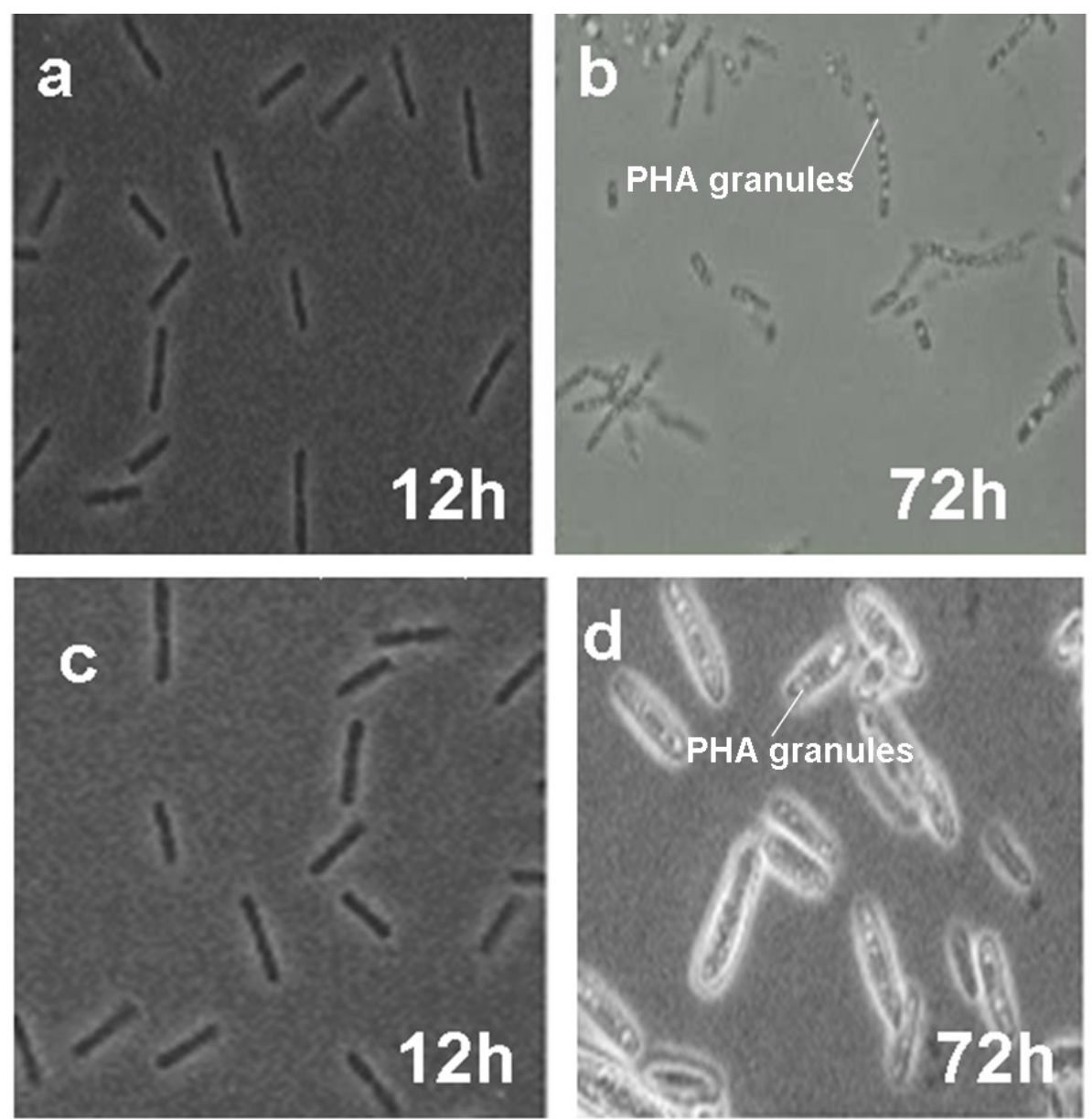

Figure 1. Phase contrast microscopic view of recombinant E.coli harboring partial phaCl gene

a. Recombinant E.coli grown for $12 \mathrm{~h}$ in Sucrose

b. Recombinant E.coli grown for $72 \mathrm{~h}$ in Sucrose

c. Recombinant E.coli grown for $12 \mathrm{~h}$ in Molasses

d. Recombinant E.coli grown for $72 \mathrm{~h}$ in Molasses 

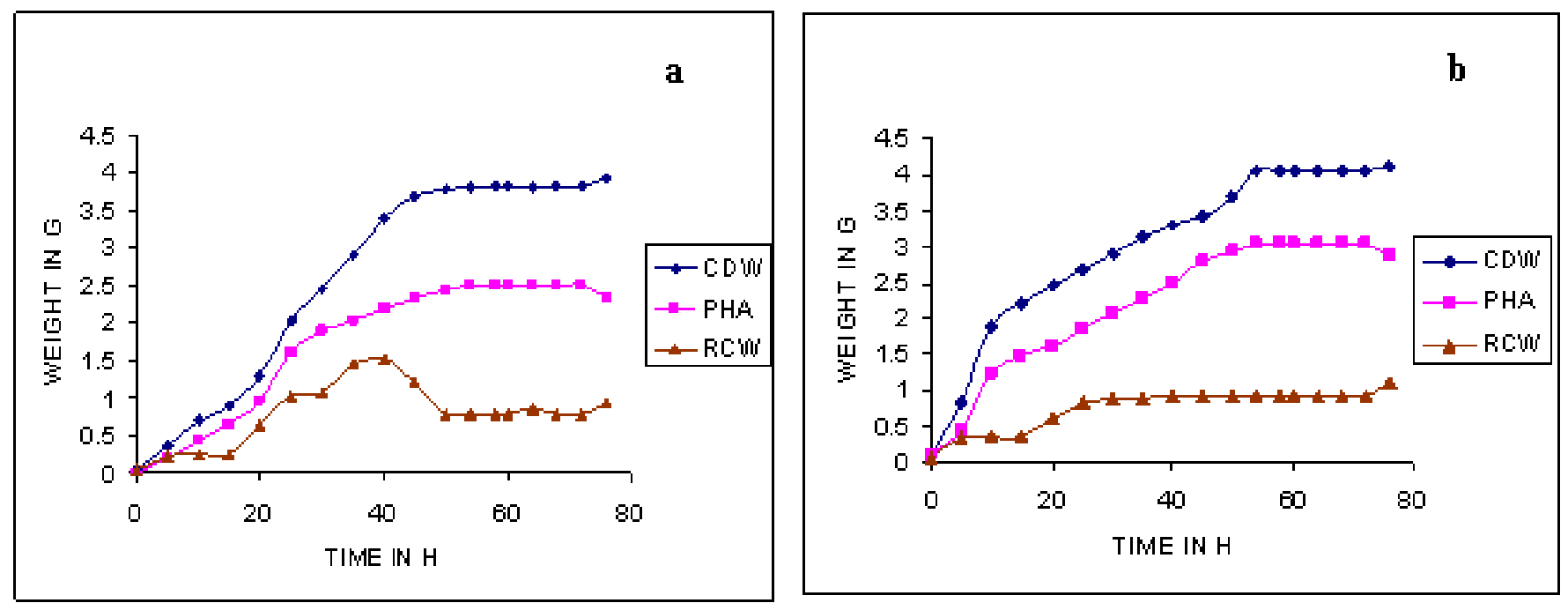

Figure 2. Growth kinetics of recombinant E.coli

a. PHA production per Litre by recombinant E.coli grown using Sucrose

b. PHA production per Litre by recombinant E.coli using Molasses

CDW - Cell Dry Weight ; PHA - Polyhydroxyalkanoate;

RCW - Residual Cell Weight

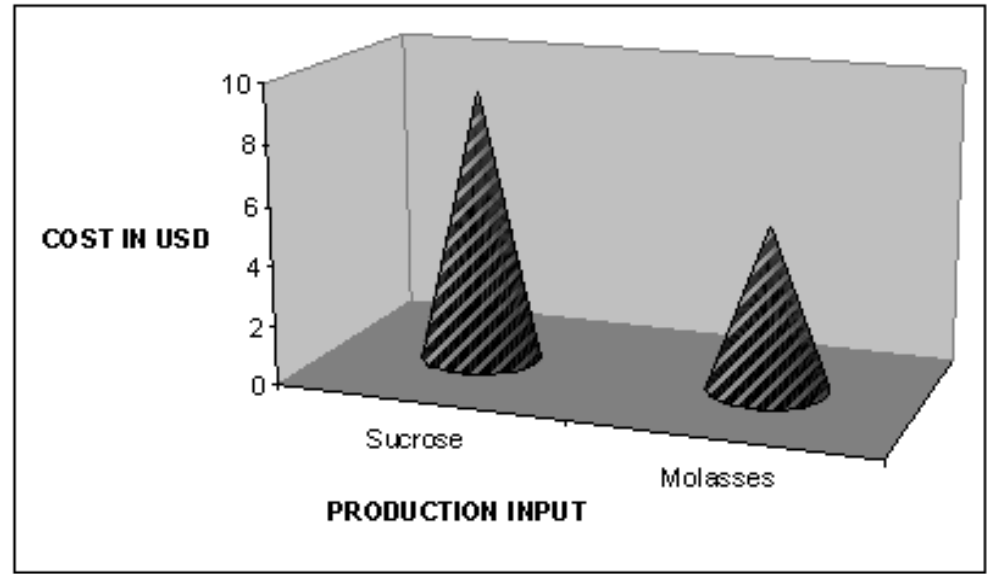

Figure 3. Economic analysis: Production of one gram of PHA

\section{TLC identification of PHA}

PHA components were identified with the characteristic appearance of yellowish green colour spot in the TLC plates. The retention factor $\left(R_{f}\right)$ was 0.58 for both the samples in accordance with reports of Paul et al (2004).

\section{DSC analysis of PHA}

Melting temperature $\left(\mathrm{T}_{\mathrm{m}}\right)$ is determined from endothermal peaks of the DSC thermograms. PHA recovered from the strain cultured with molasses had $\mathrm{T}_{\mathrm{m}}$ of $129.59^{\circ} \mathrm{C}$ (Figure $4 \mathrm{a}$ ) is indeed lower than that with sucrose $\left(\mathrm{T}_{\mathrm{m}} 152^{\circ} \mathrm{C}\right.$ ) (Figure $\left.4 \mathrm{~b}\right) . \mathrm{T}_{\mathrm{m}}$ is influenced by the length of side chain and functional groups present (5). Lower $\mathrm{T}_{\mathrm{m}}$ indicates that the side chains are longer. Molasses had incorporated longer side chains in comparison with sucrose. The range of $\mathrm{T}_{\mathrm{m}}$ reported in this study suits fabrication of product as per ASTM: D 882-91 test (21). 

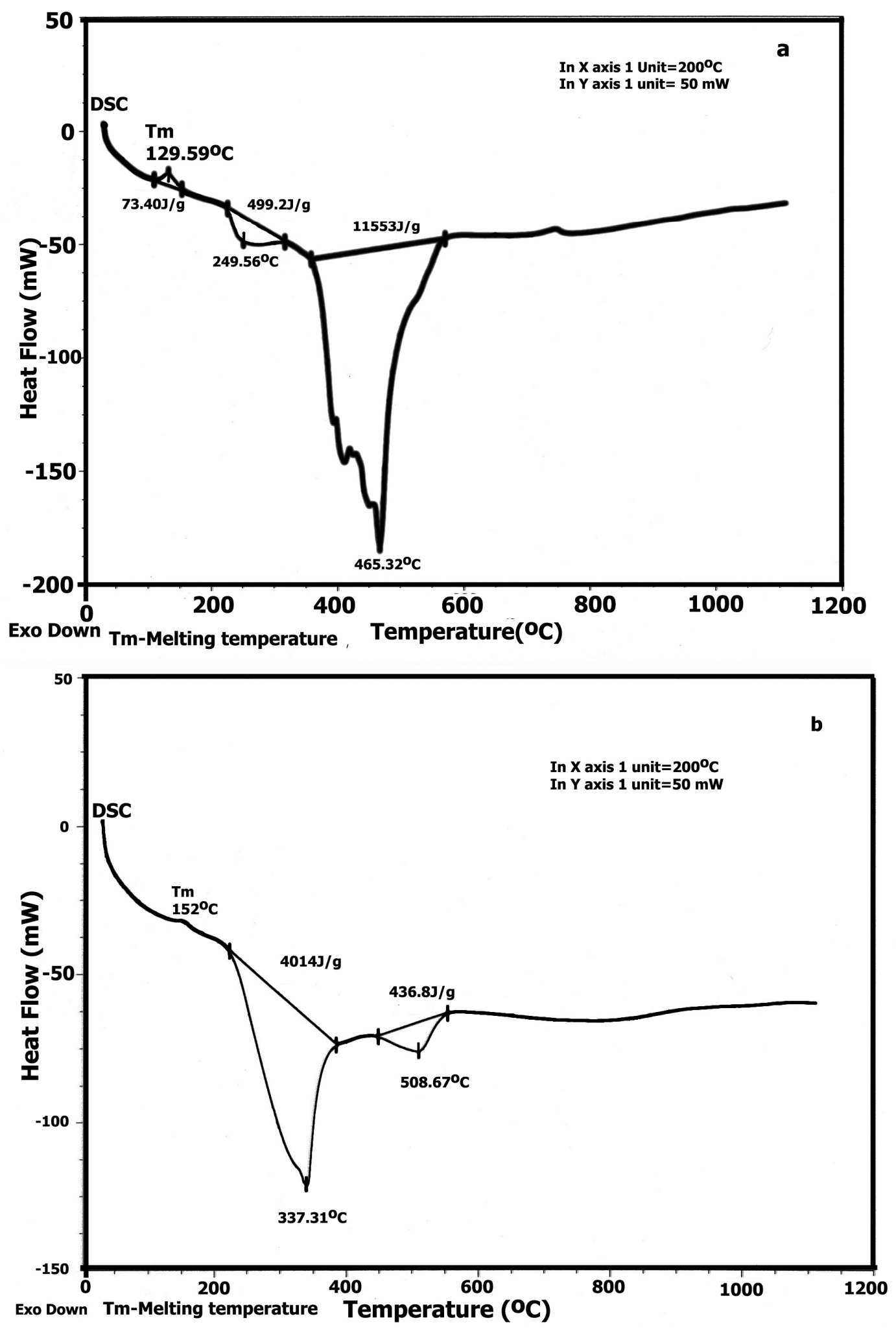

Figure 4. Thermal analysis: Melting temperature determination from DSC thermogram

a. PHA produced from Recombinant E.coli by fermentation of molasses

b. PHA produced from Recombinant E.coli by fermentation of sucrose 
TGA \& DTA analysis of PHA

Thermal stability of PHA is important for their melt processing. The temperature at $5 \%$ weight loss termed $\mathrm{T}_{\mathrm{d}(5 \%)}$ was employed to evaluate polymer thermal stability. PHA samples recovered from recombinant strain cultured with molasses had $\mathrm{T}_{\mathrm{d}(5 \%)}$ of $240{ }^{\circ} \mathrm{C}$ (Figure 5a). The PHA sample from the strain cultured with sucrose had $\mathrm{T}_{\mathrm{d}(5 \%)}$ of $310^{\circ} \mathrm{C}$ (Figure $5 \mathrm{~b}$ ). $\mathrm{T}_{\mathrm{d}(5 \%)}$ was much higher than $\mathrm{T}_{\mathrm{m}}$ reflecting thermal permanence. This validates the improved avenues for polymer processing (21).
DTA helps to determine the heat of reaction of decomposition process. If cross linking reactions occurred during degradation of PHA, an exothermic peak would be detected in DTA thermogram. The temperature at which cross linking occurs is the curing temperature. The curing temperature for cost effectively produced PHA is around $431^{\circ} \mathrm{C}$. This stands to be a valid property as major barrier for commercial application of PHA, was their thermal instability due to lack of ability to crosslink (10).

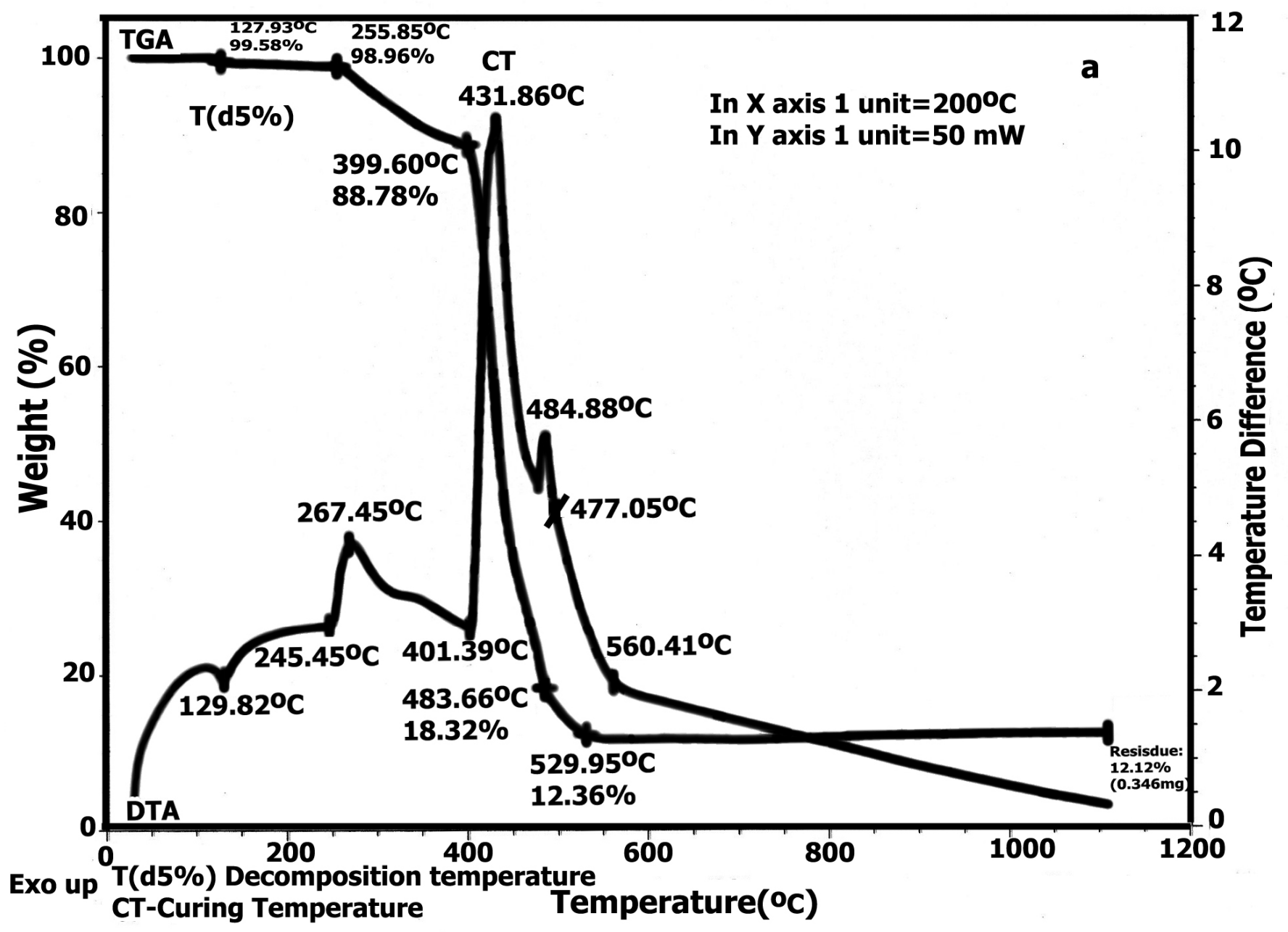

Figure 5. TGA and DTA thermogram for determination of Decomposition and curing Temperature

a. PHA produced from Recombinant E.coli by fermentation of molasses 




Figure 5. TGA and DTA thermogram for determination of Decomposition and curing Temperature

b. PHA produced from Recombinant E.coli by fermentation of sucrose

\section{Examination of Optical rotation}

The optical rotation of methyl ester of PHA from molasses as well as sucrose grown cells was negative $(-1)$ which indicates that $\mathrm{R}$ form is enantiomerically excess in accordance with earlier reports (6).

\section{GC-MS analysis of PHA}

GC-MS analysis helps in elucidating the structure of components. The key compounds of concern were identified based on their retention peak. PHA from recombinant E.coli cultured with molasses significantly contained $\mathrm{C}_{9} \mathrm{H}_{20} \mathrm{O}_{3}$ (Propane - 1, 1 triethoxy-) and $\mathrm{C}_{12} \mathrm{H}_{26}$ (Dodecane) (Figure 6). These compounds signify that the monomer chains were of biodegradable polyester family (11). Characteristic fragment at $\mathrm{m} / \mathrm{z} 103$ suggested the presence of hydroxyl group of carbon 3 formed by cleavage of alpha to the hydroxylated carbon (12). This had made apparent that financial prudence effort had no way compromised the eminence of artifact.

PHA recovered from sucrose grown cultures had significant compounds like $\mathrm{C}_{12} \mathrm{H}_{24} \mathrm{O}_{3}$ (Dodecanoic acid 3-hydroxyl-) and $\mathrm{C}_{14} \mathrm{H}_{30}$ (Tetradecane) (Figure 7). These are biodegradable by virtue of hydrolysable ester bonds (4). The components identified had served as evident for the verity that nutrient and culture conditions modify the side chain length.

PHA production by recombinant E.coli harboring phaCl gene was studied using molasses as nutrient substrate, indeed to lower the production cost. Its effect on properties was tracked and it's now evident that molasses as a substrate did not adversely affect material properties and in fact had led to betterment. This study will lead to economic PHA production appropriate for large scale intended for commercialization. 


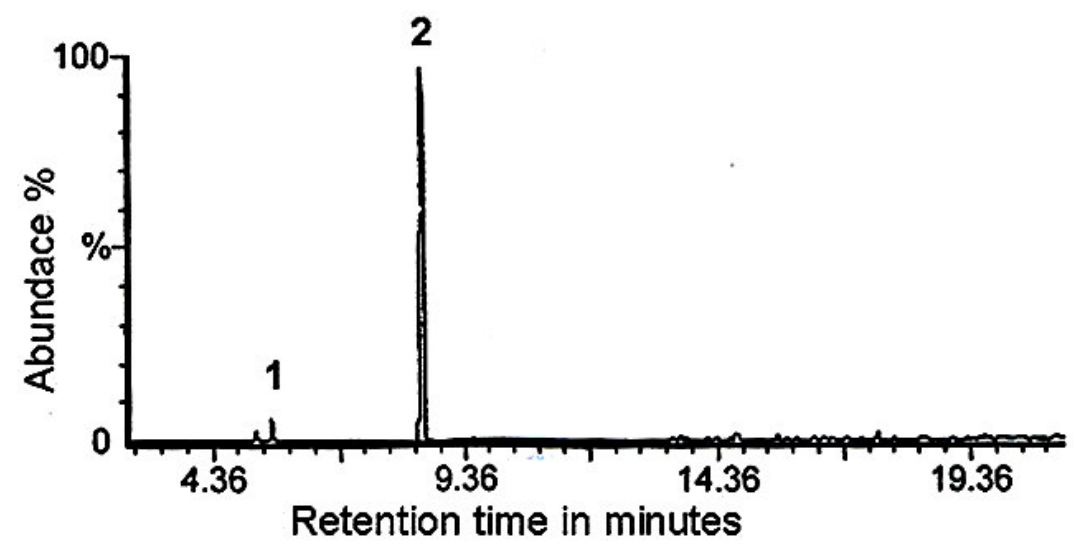



Propane 1,1 triethoxy (Rt 5.96 minutes)

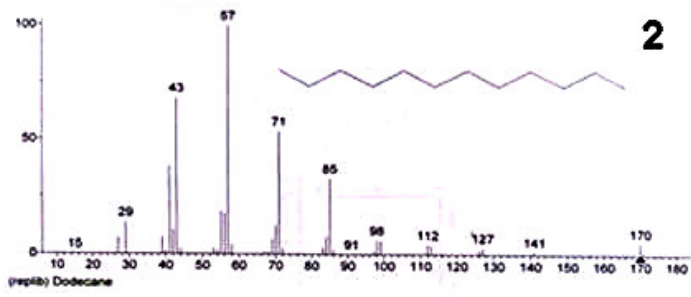

Dodecane (Rt 8.93 minutes)

Figure 6. GC/MS analysis of PHA produced from Recombinant E.coli by fermentation of molasses

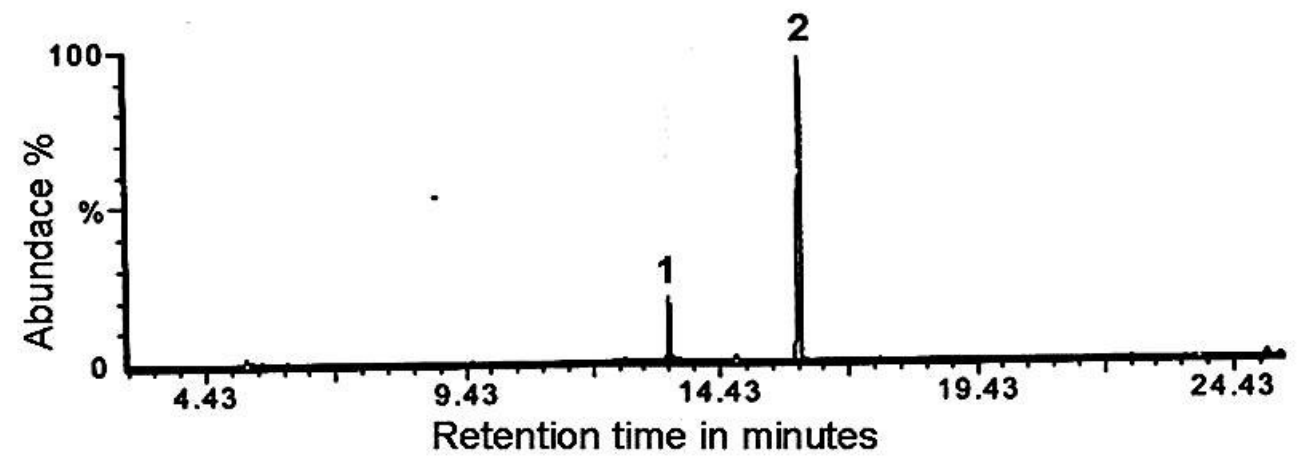

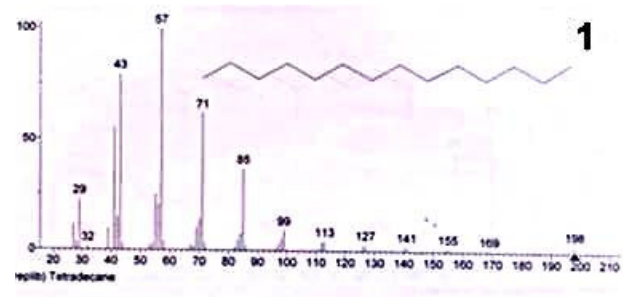

Tetradecane (Rt 13.75 minutes)



Dodecanoic acid 3 hydroxy (Rt 15.34 minutes)

Figure 7. GC/MS analysis of PHA produced from Recombinant E.coli by fermentation of sucrose 


\section{ACKNOWLEDGEMENT}

Thanks to the financial support by DBT, India vide project reference "BT/PR 10211/ BCE/08/615/ 2007", DBT-BIF and "BT/PR11256/PID/06/450/2008". Dr.Sujatha is thankfully acknowledged for providing the strain. Support of Dr. Peterselvanayagam, Dr.Binu Ramesh, Dr.Mahalakshmi, Mrs. Poornimak kani, Ida, Abirami, Priyadarsini, Suguna, Rajeswari, Asnet Mary and Poorna is thankfully accredited.

\section{REFERENCES}

1. Brandl, H.; Gross, R.A.; Lenz, R.W.; Fuller, R.C. (1988) Pseudomonas oleovorans as a source of poly ( $\beta$-hydroxyalkanoates) for potential applications as biodegradable polyesters. Appl Environ Microbiol 54, 1977-1982.

2. Dawes, E.A.; Senior, P.J. (1973). The role and regulation of energy reserve polymers in microorganisms. Adv Micro Physiol. 10, 135-266.

3. De Campos, A.; Franchetti, S.M.M.; Agnelli, J.A.M. (2003). Biotransformation of poly (epsilon-caprolactone) and poly (vinyl chloride) blend. Braz. J. Microbiol. 34(1), 111-113.

4. Doi, Y.; Kitamura, S.; Abe. H. (1995). Microbial synthesis and characterization of poly (3-hydroxybutyrate-co-3-hydroxyhexanoate). Macromol. 28,4822-4828.

5. Eggink, G.; Northolt, M.D. (1995). Method for producing a biologically degradable Polyhydroxyalkanoates coating with the aid of an aqueous dispersion of Polyhydroxyalkanoates. Polymer.42, 3296-9.

6. Haywood, G.W.; Anderson, A.J.; Ewing, D.F.; E.A.Dawes. (1990) Accumulation of a polyhydroxyalkanoate containing primariliy 3hydroxy decanoate from simple carbohydrate substrate by Pseudomonas sp. Strain NCIB 40135. Appl.Environ.Micriobiol. 56, 3354-3359.

7. Ismaiel , A.A. ; El-Sayed , E.A.; Mahmoud, A.A. (2010). Some optimal culture conditions for production of cyclosporin a by Fusarium roseum. Braz. J. Microbiol. 41(4 ), 1112-1123.

8. Jan, S.; Courtois, J.; Courtois, B.; Goethals, G.; Nava saucedo, J. E.; J. N. Barbotin. (1993) In: Colloque Bioencapsulation III. The reality of a new industrial tool, Bruxelles, Institut Meurice Ceria, 116.

9. Kumar. S; prabakaran, G. (2006) Production of PHB (bioplastic) using bio-effluent as substrate by Alcaligens eutrophus. Indian Journal of

biotech. 5, 76-79.

10. Lee, S.Y.; Park, S. J. (2001) Production of poly (3-ydroxybutyrate) from whey by cell recycle fed-batch culture of recombinant Escherichia coli, Biotechnol. Lett. 23, 235-240.
11. Lee, S.Y.; Choi, J. (1997) Process analysis and economic evaluation for poly (3-hydroxybutyrate) production by fermentation, Bioprocess. Eng. 17, 335-342.

12. McLafferty F.W.; Turecek, F. (1993) Interpretation of Mass Spectra (4th ed.), University Science Books, Mill Valley .

13. Muller, R.J.; Kleeberg, I.; Deckwer, W.D. (2001). Biodegradation of polyesters containing aromatic constituents. J. Biotechnol. 86, 87-95.

14. Nomura, T.C.; Taguchi, K.; Gan, Z.; Kuwabara, K.; Tanaka, T.; Takase, K; Doi, Y. (2005) Expression of 3-ketoacyl-Acyl Carrier Protein Reductase $(f a b G)$ Genes Enhances Production of Polyhydroxyalkanoate Copolymer from Glucose in Recombinant Escherichia coli JM109. Appl Environ Microbiol 71, 4297-4306.

15. Oliveira , R.C.; Gomez, J.G.C.; Torres, B.B.; Netto, C.L.B.; Da Silva, L.F. (2000). A suitable procedure to choose antimicrobials as controlling agents in fermentations performed by bacteria. Braz. J. Microbiol. 31 (2), 87-89.

16. Otenio, M.H.; Da Silva, M.T.L.; Marques, M.L.O.; Roseiro, J.C.; Bidoia, E.D. (2005). Benzene, Toluene, and Xylene Biodegradation by Pseudomonas putida CCMI 852. Braz. J. Microbiol. 36(3), 258-261.

17. Paul, D.; Chauhan, A. (2004 ). Degradation of $p$-hydroxybenzoate via protocatechuate in Arthrobacter protophormiae RKJ100 and Burkholderia cepacia RKJ200. Current science. 87, 1673-8.

18. Saranya, V.; Shenbagarathai, R. (2010). Effect of Nitrogen and Calcium Sources on Growth and Production of PHA of Pseudomonas sp. LDC-5 and its Mutant. Curr.Res.J.Biol.Sci. 2 (3), 164-167.

19. Sujatha, K.; Shenbagarathai. R. (2006) A study on MCL polyhydroxyalkanoate accumulation in E.coli harbouring phaC gene of indigenous Pseudomonas sp. LDC-5. Lett Appl Microbiol. 43 (6), 607614.

20. Swain, M.R.; Kar, S.; Ray, R.C. (2009). Exo-polygalacturonase production by Bacillus subtilis CM5 in solid state fermentation using cassava bagasse. Braz. J. Microbiol. 40(3) 636-648.

21. Tang, Z.G.; Black, R.A.; Curran, J.M.; Hunt, J.A.; Rhodes, N.P.; Williams, D.F. (2004). Surface properties and biocompatibility of solvent-cast poly [ $\varepsilon$-caprolactone] films. Biomaterials. 25, 4741-4748.

22. Verlinden, R.A.J.; Hill, D.J.; Kenward,M.A.; Williams,C.D.; Radecka.I. (2007) Bacterial synthesis of biodegradable polyhydroxyalkanoates. $J$ Appl Microbiol. 102(6), 1437-1449.

23. Wegen, R.J.V.; Lee, S.Y.; Middelberg, A.P.J. (2001) Metabolic and Kinetic Analysis of Poly(3-Hydroxybutyrate) Production by Recombinant Escherichia coli. Biotechnol Bioeng. 74 (1), 70-80.

24. Zinn, M.; Hany. R. (2005) Tailored material properties of polyhydroxyalkanoates through biosynthesis and chemical modification. Adv Eng Mater. 7, 408-411. 




